Check for updates

Cite this: New J. Chem., 2019, 43, 17863

Received 14th May 2019,

Accepted 14th October 2019

DOI: 10.1039/c9nj02495f

rsc.li/njc

\section{Tuning the interactions of decavanadate with thaumatin, lysozyme, proteinase $K$ and human serum proteins by its coordination to a pentaaquacobalt(II) complex cation $\dagger$}

\author{
Lukáš Krivosudský, (D) ‡a Alexander Roller (D) ${ }^{b}$ and Annette Rompel (D) *a
}

\begin{abstract}
The decavanadate anion, $\mathrm{H}_{x} \mathrm{~V}_{10} \mathrm{O}_{28}{ }^{(6-x)-}\left(\mathbf{V}_{\mathbf{1 0}}\right)$, is one of the most studied vanadium polyoxometalate species. In recent decades several works have pointed to its biological relevance coming mainly from its ability to bind to proteins (such as actin, myosin or ion pumps). On the other hand, non-functional binding was observed in several protein crystal structures, where $\mathbf{V}_{\mathbf{1 0}}$ was incorporated "accidentally" resulting from the presence of $\mathrm{Na}_{3} \mathrm{VO}_{4}$ as a phosphatase inhibitor. In this work we broaden the potential biological applications of $\mathbf{V}_{\mathbf{1 0}}$ by presenting the synthesis and characterization of two decavanadate species where the anion acts as a ligand: (2-hepH) $\left(\mathrm{NH}_{4}\right)\left[\left\{\mathrm{Cu}\left(\mathrm{H}_{2} \mathrm{O}\right)_{2}(2-h e p)\right\}_{2} \mathrm{~V}_{10} \mathrm{O}_{28}\right] \cdot 4 \mathrm{H}_{2} \mathrm{O}\left(\mathbf{V}_{10} \mathrm{Cu}\right)$ and $(2-h e p H)_{2}\left[\left\{\mathrm{Co}\left(\mathrm{H}_{2} \mathrm{O}\right)_{5}\right\}_{2} \mathrm{~V}_{10} \mathrm{O}_{28}\right] \cdot 4 \mathrm{H}_{2} \mathrm{O}\left(\mathrm{V}_{10} \mathrm{Co}\right)(2-h e p=2$-hydroxyethylpyridine). Unlike free decavanadate, the complex anions stay intact in model buffer solutions $(0.1 \mathrm{M} 2$-(N-morpholino)ethanesulfonic acid, $0.5 \mathrm{M} \mathrm{NaCl}, \mathrm{pH}=5.8$ and 8.0). It has been shown that $\mathbf{V}_{\mathbf{1 0}} \mathrm{Co}_{\mathbf{0}}$ is stable also in the presence of proteins and for the first time it was possible to study the interaction of decavanadate with proteins without the interference of lower vanadate oligomers. This allowed comparison of interactions of $\mathbf{V}_{\mathbf{1 0}}$ and $\mathbf{V}_{\mathbf{1 0}} \mathbf{C o}$ with the model proteins thaumatin, lysozyme, proteinase $K$, human serum albumin and transferrin under conditions close to biological ones (0.1 M 2-( $N$-morpholino)ethanesulfonic acid, $0.5 \mathrm{M} \mathrm{NaCl}, \mathrm{pH}=5.8)$. The linewidths of the signals at half-height in ${ }^{51} \mathrm{~V}$ NMR spectra reflect the strength of interaction of a vanadium species with a protein, and thus it was shown that $\mathbf{V}_{\mathbf{1 0}}$ and $\mathbf{V}_{\mathbf{1 0}}$ Co both bind strongly to thaumatin, $\mathbf{V}_{\mathbf{1 0}}$ binds to lysozyme and $\mathbf{V}_{\mathbf{1 0}} \mathbf{C o}$ binds to proteinase $\mathrm{K}$. $\mathbf{V}_{\mathbf{1 0}}$ interacts with both human serum albumin and transferrin, but surprisingly $\mathbf{V}_{\mathbf{1 0}} \mathrm{Co}$ exhibits high affinity to transferrin but does not interact with albumin.
\end{abstract}

\section{Introduction}

Polyoxometalates (POMs) are an important group of metal oxide clusters $^{1}$ exhibiting diverse archetypal structures of, particularly, vanadates, molybdates and tungstates. ${ }^{2-4}$ The tremendous variability of POMs has given rise to their application in distinct areas of materials science, ${ }^{5,6}$ catalysis, ${ }^{7-10}$ electrochemistry and redox processes, ${ }^{11,12}$ photochemistry ${ }^{13-15}$ and magnetism. ${ }^{16-18}$ In recent years, the roles of POMs in biological systems have been intensively investigated. Such studies may be divided

\footnotetext{
${ }^{a}$ Universität Wien, Fakultät für Chemie, Institut für Biophysikalische Chemie, Althanstraße 14, Wien 1090, Austria. E-mail: annette.rompel@univie.ac.at; Web: http://www.bpc.univie.ac.at

${ }^{b}$ Universität Wien, Fakultät für Chemie, Zentrum für Röntgenstrukturanalyse, Währinger Straße 42, 1090 Wien, Austria

$\dagger$ Electronic supplementary information (ESI) available. CCDC 1909250 and 1909251. For ESI and crystallographic data in CIF or other electronic format see DOI: 10.1039/c9nj02495f

\# Comenius University in Bratislava, Faculty of Natural Sciences, Department of Inorganic Chemistry, Ilkovičova 6, 84215 Bratislava, Slovakia.
}

into two groups: functional binding and interaction of POMs in biological systems widening the borders of medicinal chemistry; ${ }^{19-24}$ and non-functional interaction with biomolecules, such as proteins, enhancing the current possibilities in macromolecular crystallography by promoting the crystallization or being useful in obtaining the initial phases while solving the structures of proteins. ${ }^{25-28}$

Decavanadate, $\mathrm{H}_{x} \mathrm{~V}_{10} \mathrm{O}_{28}{ }^{(6-x)-}\left(\mathbf{V}_{\mathbf{1 0}}\right)$, is the predominant species formed in vanadate solutions at vanadium(v) concentrations above $1 \mathrm{mM}$ in the $\mathrm{pH}$ range of $\approx 2-6 .{ }^{29,30}$ The structure of $\mathbf{V}_{\mathbf{1 0}}$ consists of ten face-sharing octahedra (Scheme 1). The symmetrically non-equivalent vanadium atoms $\mathrm{V}_{\mathrm{A}}, \mathrm{V}_{\mathrm{B}}$ and $\mathrm{V}_{\mathrm{C}}$ give rise to three different signals in ${ }^{51} \mathrm{~V}$ NMR spectra depending on the conditions: while the low-field signal of $\mathrm{V}_{\mathrm{A}}$ atoms stays in a narrow region around $-425 \pm 3 \mathrm{ppm}$, the other two peaks representing $\mathrm{V}_{\mathrm{B}}$ and $\mathrm{V}_{\mathrm{C}}$ atoms are more sensitive to changes in acidity and exhibit signals at approximately $-505 \pm 10 \mathrm{ppm}$ and $-525 \pm$ $10 \mathrm{ppm}$, respectively. The oxygen atoms $\mathrm{O}_{\mathrm{B}}$ and $\mathrm{O}_{\mathrm{C}}$ are potential sites for protonation, and the atoms $\mathrm{O}_{\mathrm{C}}, \mathrm{O}_{\mathrm{F}}, \mathrm{O}_{\mathrm{G}}$ and $\mathrm{O}_{\mathrm{D}}$ are the most potential sites for ligation to transition metal ions. ${ }^{31,32}$ 


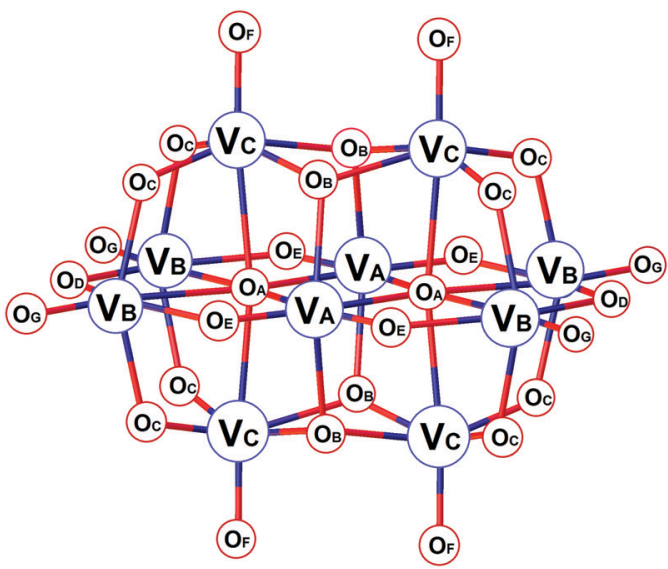

Scheme 1 The structure of $\left[\mathrm{V}_{10} \mathrm{O}_{28}\right]^{6-}$ showing different types of vanadium and oxygen atoms.

As such, changes in ${ }^{51} \mathrm{~V}$ NMR parameters reflect the versatility of structural modifications of $\mathbf{V}_{\mathbf{1 0}}$. While protonation and coordination of $\mathbf{V}_{\mathbf{1 0}}$ manifest mostly in peaks' movement, the interaction and binding to proteins result in significant peak broadening defined by linewidths at half-height of the signals, $W_{1 / 2}$. This is caused by the ligand bulkiness and decreased symmetry of the $\mathbf{V}_{\mathbf{1 0}}$ species upon interaction. ${ }^{32}$

Vanadium is naturally omnipresent in biological matrices ${ }^{33,34}$ in a few enzymes such as vanadium dependent haloperoxidases and nitrogenases ${ }^{35}$ or acts as a crucial component in the energetic metabolism of Ascidians. ${ }^{36}$ Some artificial vanadium compounds, on the other hand, exhibit insulin mimetic properties, antitumor activity, antibacterial activity or anti-HIV activity. ${ }^{35-39}$

Specifically decavanadate itself has also been studied with respect to many biological aspects, ${ }^{40-43}$ and it was shown that $\mathbf{V}_{\mathbf{1 0}}$ binds to several proteins such as actin, ${ }^{44}$ myosin, ${ }^{45}$ ion pump $\mathrm{Ca}^{2+}$-ATPase, ${ }^{46}$ bovine serum albumin and gelatine, ${ }^{47}$ and microtubule-associated proteins. ${ }^{48}$ Protein crystallography revealed the presence of $\mathbf{V}_{\mathbf{1 0}}$ in the crystal structures of acid phosphatase $\mathbf{A}$ (F. tularensis) ${ }^{49}$ human activated receptor tyrosine kinase, ${ }^{50}$ NTPDase1 (L. pneumophila), ${ }^{51}$ NTPDase1 (R. norvegicus), ${ }^{52}$ and human TRPM4 channel. ${ }^{53}$ In all cases, $\mathbf{V}_{\mathbf{1 0}}$ was formed from the initially employed $\mathrm{Na}_{3} \mathrm{VO}_{4}$ (used as a phosphatase inhibitor) and its role may be explained as stabilization and rigidification of the protein structure. ${ }^{25}$

In this work we compare the interaction of both free and ligated decavanadate with commercially available model proteins thaumatin, lysozyme, proteinase $\mathrm{K}$, as well as human serum albumin and transferrin. We utilize ${ }^{51} \mathrm{~V}$ NMR spectroscopy as a powerful tool to investigate the stability of two decavanadates coordinated to metal centres $\mathrm{Cu}(\mathrm{II})$ and $\mathrm{Co}(\mathrm{II})$ under conditions usually used for protein crystallization.

\section{Experimental}

\subsection{Materials and methods}

All chemicals were of analytical grade and used as received without further purification. All proteins were supplied as lyophilized powders (supplier, reference code): thaumatin from
Thaumatococcus danielii (Sigma, T7638; a mixture of thaumatin I and thaumatin II with traces of other sweet proteins), proteinase $\mathrm{K}$ from Tritirachium album (Sigma, P6556), lysozyme from chicken eggwhite (Carl Roth GmbH \& Co. KG, 8259.3), albumin from human serum (Sigma, A1653) and apo-transferrin from human serum (Sigma, T1147). The determination of C/H/N was carried out by using an 'EA 1108 CHNS-O' elemental analyzer by Carlo Erba Instruments at the Mikroanalytisches Laboratorium, University of Vienna. Metal elements' analyses were performed in aqueous solutions containing $2 \% \mathrm{HNO}_{3}$ using inductively coupled plasma mass spectrometry (PerkinElmer Elan 6000 ICP MS) for Mo and V, and atomic absorption spectroscopy (PerkinElmer 1100 Flame AAS) for $\mathrm{Cu}$ and Co. Standards were prepared from single-element standard solutions of concentration $1000 \mathrm{mg} \mathrm{L}^{-1}$ (Merck, Ultra Scientific and Analytika Prague). FT-IR spectroscopy was performed on a Bruker Vertex 70 IR Spectrometer equipped with a single reflection diamond-ATR (attenuated total reflectance) unit in the range of $4000-100 \mathrm{~cm}^{-1}$.

\section{$2.2 \quad{ }^{51} \mathrm{~V}$ NMR spectroscopy}

${ }^{51} \mathrm{~V}$ nuclear magnetic resonance spectroscopy measurements of aqueous solutions were performed on a Bruker Avance II $500 \mathrm{MHz}$ instrument operating at $131.60 \mathrm{MHz}$ for ${ }^{51} \mathrm{~V}$ nucleus (2000 scans, accumulation time $0.05 \mathrm{~s}$, relaxation delay $0.01 \mathrm{~s}$ ). Chemical shift values are given with reference to $\operatorname{VOCl}_{3}(\delta=0 \mathrm{ppm})$ as a standard. The solutions were in general prepared by dissolving $0.01 \mathrm{mmol}$ of the given decavanadate in $700 \mu \mathrm{L}$ of the buffer solution $(0.11 \mathrm{M}$ MES, $0.55 \mathrm{M} \mathrm{NaCl}, \mathrm{pH}=5.8$; MES = 2 -( $N$-morpholino)ethanesulfonic acid) and addition of $100 \mu \mathrm{L}$ of $\mathrm{D}_{2} \mathrm{O}$ used for locking. Next, the solution was either made up to $1000 \mathrm{~s} \mu \mathrm{L}$ with the buffer (Section 3.3.1) or a solution of a protein in the same buffer was slowly added. The protein solutions were prepared by dissolution of the given amount of solid protein in $200 \mu \mathrm{L}$ of the buffer solution. The solution of proteinase $\mathrm{K}$ was prepared as $3.5 \mathrm{M}$ solution in $0.1 \mathrm{M}$ TRIS (tris(hydroxymethyl)aminomethane) buffer $(\mathrm{pH}=7.0)$, and subsequently $1 \mu \mathrm{L}$ of this solution was diluted in $200 \mu \mathrm{L}$ of the MES buffer solution. The spectra were collected at RT one hour after preparation of the solutions.

\subsection{X-ray diffraction on single crystals}

The X-ray diffraction data were collected on Bruker X8 APEXII $\left(\mathbf{V}_{\mathbf{1 0}} \mathbf{C u}, \mathrm{Mo} \mathrm{K} \alpha\right)$ and Bruker D8 Venture $\left(\mathbf{V}_{\mathbf{1 0}} \mathbf{C o}, \mathrm{Cu} \mathrm{K} \alpha\right)$ instruments equipped with multilayer monochromators, Incoatec Microfocus sealed tubes, and Kryoflex and Oxford cooling devices. The structures were solved by direct methods and refined by fullmatrix least-squares. Nonhydrogen atoms were refined with anisotropic displacement parameters. Hydrogen atoms were inserted at calculated positions and refined with riding coordinates except for solvent molecules and $\mathrm{H}$ atoms in $\mathrm{NH}_{4}{ }^{+}$in $\mathbf{V}_{\mathbf{1 0}} \mathbf{C u}$. This was not done because of disorder and partial occupancies of $\mathrm{O}$ and $\mathrm{N}$ atoms in question. The following software was used for the structure solving procedure: Bruker SAINT software package ${ }^{54}$ (frame integration, cell refinement), SADABS $^{55}$ (absorption correction), SHELXS-2013 ${ }^{56}$ (structure solution), SHELXL-2013 ${ }^{57}$ (structure refinement), OLEX2 ${ }^{58}$ (user interface and publication 
material) and Diamond ${ }^{59}$ (graphics). Experimental data and CCDC-codes can be found in Table 2 .

\subsection{Syntheses}

$\left(\mathrm{NH}_{4}\right)_{6}\left[\mathrm{~V}_{10} \mathrm{O}_{28}\right] \cdot 6 \mathrm{H}_{2} \mathrm{O}\left(\mathbf{V}_{10}\right)$ : the compound was prepared as per the previously described procedure ${ }^{60}$ and the composition was confirmed by FT-IR spectroscopy and elemental analysis. Analytical data for $\mathrm{V}_{10} \mathrm{O}_{34} \mathrm{~N}_{6} \mathrm{H}_{36}$ in \% (calc.): $\mathrm{V} 46.3$ (43.4). IR: $\left[\mathrm{V}_{10} \mathrm{O}_{28}\right]^{6-}: 958 \mathrm{vs}, 816 \mathrm{~m}, 727 \mathrm{~s}, 588 \mathrm{~m}, 516 \mathrm{~s}, 452 \mathrm{~s}, 392 \mathrm{vs}$; $\mathrm{NH}_{4}^{+}: 1405 \mathrm{~s}, 3151 \mathrm{sh}, 3009 \mathrm{sh}, 2008 \mathrm{sh}$.

$(2-h e p \mathrm{H})\left(\mathrm{NH}_{4}\right)\left[\left\{\mathrm{Cu}\left(\mathrm{H}_{2} \mathrm{O}\right)_{2}(2-h e p)\right\}_{2} \mathrm{~V}_{10} \mathrm{O}_{28}\right] \cdot 4 \mathrm{H}_{2} \mathrm{O} \quad\left(\mathbf{V}_{\mathbf{1 0}} \mathbf{C u}\right)$ : $\mathrm{NH}_{4} \mathrm{VO}_{3}(0.468 \mathrm{~g}, 4 \mathrm{mmol})$ was dissolved in $30 \mathrm{~mL}$ of distilled water by heating. After cooling to RT, the $\mathrm{pH}$ of the solution was adjusted to 4.6 with $5 \mathrm{M} \mathrm{HCl}$. Then, 2-hep (2-hep = 2-hydroxyethylpyridine) was added $(0.45 \mathrm{~mL}, 4 \mathrm{mmol})$ and the $\mathrm{pH}$ was adjusted to 4.6 with $5 \mathrm{M} \mathrm{HCl}$ again. Finally, $\mathrm{Cu}\left(\mathrm{NO}_{3}\right)_{2} \cdot 6 \mathrm{H}_{2} \mathrm{O}$ was added $(0.484 \mathrm{~g}, 2 \mathrm{mmol})$. After dissolution, the $\mathrm{pH}$ dropped to 4.0. The clear orange-green solution was left to crystallize at $18{ }^{\circ} \mathrm{C}$. After three days, green crystals of $\mathbf{V}_{\mathbf{1 0}} \mathbf{C u}$ were isolated. Yield $250 \mathrm{mg}$ (39\% based on V). Analytical data for $\mathrm{V}_{10} \mathrm{Cu}_{2} \mathrm{O}_{39} \mathrm{C}_{21} \mathrm{H}_{48} \mathrm{~N}_{4}$ in \% (calc.): V 30.7 (31.5), Cu 7.76 (7.86), C 15.36 (15.60), H 3.02 (3.00), N 3.41 (3.46). IR: $\left[\mathrm{V}_{10} \mathrm{O}_{28}\right]^{6-}:$ 983s, 959vs, 937s, 850s, 793s, 721s, 512s, 429s, 386s; 2-hep: 1609m, 1488m, 1313m, 1248w, 1109w, 1073w, 1051w, 1025w; $\mathrm{NH}_{4}^{+}$: 1439s, 3210sh.

$(2-h e p \mathrm{H})_{2}\left[\left\{\mathrm{Co}\left(\mathrm{H}_{2} \mathrm{O}\right)_{5}\right\}_{2} \mathrm{~V}_{10} \mathrm{O}_{28}\right] \cdot 4 \mathrm{H}_{2} \mathrm{O} \quad\left(\mathbf{V}_{10} \mathbf{C o}\right)$ : a procedure similar to that in the previous synthesis was employed, except that upon addition of $\mathrm{Co}\left(\mathrm{NO}_{3}\right)_{2} \cdot 6 \mathrm{H}_{2} \mathrm{O}(0.596 \mathrm{~g}, 2 \mathrm{mmol})$ it was necessary to adjust the $\mathrm{pH}$ of the solution to 4.0 with $5 \mathrm{M} \mathrm{HCl}$. The clear red solution was left to crystallize at RT. After three days, red crystals of $\mathbf{V}_{10}$ Co were isolated. Yield $400 \mathrm{mg}(63 \%$ based on $\mathrm{V}$ ). Analytical data for $\mathrm{V}_{10} \mathrm{Co}_{2} \mathrm{O}_{44} \mathrm{C}_{14} \mathrm{H}_{48} \mathrm{~N}_{2}$ in \% (calc.): V 31.7 (32.3), Co 7.17 (7.48), C 10.55 (10.67), H 3.11 (3.07), N 1.82 (1.78). IR: $\left[\mathrm{V}_{10} \mathrm{O}_{28}\right]^{6-}: 989 \mathrm{~s}, 967 \mathrm{vs}, 921 \mathrm{~s}, 811 \mathrm{~s}, 724 \mathrm{~s}, 596 \mathrm{~s}, 554 \mathrm{~s}$, 505s, 446m, 398s; 2-hep: 1608m, 1772m, 1248w, 1024w. Crystals suitable for X-ray diffraction were grown by prolonged crystallization at $18{ }^{\circ} \mathrm{C}$ in a flask closed with perforated Parafilm.

\section{Results and discussion}

\subsection{Syntheses}

To the best of our knowledge, the work of Schwendt et al. ${ }^{61}$ presenting the synthesis and characterization of $(2-h e p \mathrm{H})_{2}$ $\left[\left\{\mathrm{Cu}\left(\mathrm{H}_{2} \mathrm{O}\right)_{2}(2-h e p)\right\}_{2} \mathrm{~V}_{10} \mathrm{O}_{28}\right] \cdot 6 \mathrm{H}_{2} \mathrm{O}$ is the only one reporting a coordination compound of decavanadate that stays intact in aqueous solution. Inspired by this work, the synthetic protocol was modified in order to prepare new stable complexes of decavanadate. A reversed addition of the individual reaction components and stepwise acidification of the solution prevented formation of heavy precipitates that were described in the original procedure $^{61}$ and such an approach resulted in successful isolation of $\mathbf{V}_{10} \mathbf{C u}$ containing the $\left[\left\{\mathrm{Cu}\left(\mathrm{H}_{2} \mathrm{O}\right)_{2}(2-h e p)\right\}_{2} \mathrm{~V}_{10} \mathrm{O}_{28}\right]^{2-}$ complex anion and a new compound $\mathbf{V}_{\mathbf{1 0}} \mathbf{C o}$ composed of the purely inorganic complex anion $\left[\left\{\mathrm{Co}\left(\mathrm{H}_{2} \mathrm{O}\right)_{5}\right\}_{2} \mathrm{~V}_{10} \mathrm{O}_{28}\right]^{2-}$. In this case, 2-hep did not coordinate to the cobalt(II) center and acted only as a cation. Syntheses employing $\mathrm{Ni}^{\mathrm{II}}, \mathrm{Zn}^{\mathrm{II}}, \mathrm{Mn}^{\mathrm{II}}, \mathrm{La}^{\mathrm{III}}$ and $\mathrm{Ce}^{\mathrm{III}}$ nitrates were not successful. Despite the systematic study it was
Table 1 Coordination compounds of $\mathrm{H}_{x} \mathrm{~V}_{10} \mathrm{O}_{28}{ }^{(6-x)-}$

\begin{tabular}{|c|c|c|}
\hline Compound & $\begin{array}{l}\text { Type of } \\
\text { coordinated } \\
\mathrm{O} \text { atom }{ }^{a}\end{array}$ & Ref. \\
\hline$\left[\mathrm{Cu}\left(2,2^{\prime} \text {-bipy }\right)_{2}\right]_{2}\left[\mathrm{H}_{2} \mathrm{~V}_{10} \mathrm{O}_{28}\right] \cdot\left(2,2^{\prime}-\right.$-bipy $) \cdot \mathrm{H}_{2} \mathrm{O}$ & $\mathrm{O}_{\mathrm{C}}$ & 63 \\
\hline$\left\{\left[(\mathrm{Cu} L)_{0.5}\left(\mathrm{H}_{2} L\right)_{1.5}\right]\left[\mathrm{H}_{2} \mathrm{~V}_{10} \mathrm{O}_{28}\right] \cdot 6 \mathrm{H}_{2} \mathrm{O}\right\}_{n}$ & $\mathrm{O}_{\mathrm{F}}$ & 64 \\
\hline$\left(\mathrm{NH}_{4}\right)_{2}\left[\mathrm{Cu}_{2}\left(\mathrm{NH}_{3} \mathrm{CH}_{2} \mathrm{CH}_{2} \mathrm{COO}\right)_{4}\left(\mathrm{~V}_{10} \mathrm{O}_{28}\right)\right] \cdot 10 \mathrm{H}_{2} \mathrm{O}$ & $\mathrm{O}_{\mathrm{G}}$ & 65 \\
\hline$(\mathrm{Hpz})_{2}\left[\left\{\mathrm{Cu}(p z)_{4}\right\}_{2} \mathrm{~V}_{10} \mathrm{O}_{28}\right] \cdot 2 \mathrm{H}_{2} \mathrm{O}$ & $\mathrm{O}_{\mathrm{G}}, \mathrm{O}_{\mathrm{F}}$ & 66 \\
\hline$\{\mathrm{Cu}(p z)\}_{4}\left[\left\{\mathrm{Cu}(p z)_{3}\right\}_{2} \mathrm{~V}_{10} \mathrm{O}_{28}\right]$ & $\mathrm{O}_{\mathrm{G}}, \mathrm{O}_{\mathrm{C}}$ & 66 \\
\hline$(2-h e p H)_{2}\left[\left\{\mathrm{Cu}\left(\mathrm{H}_{2} \mathrm{O}\right)_{2}(\mathrm{O}, \mathrm{N}-2-h e p)\right\}_{2}\left(\mathrm{~V}_{10} \mathrm{O}_{28}\right)\right] \cdot 6 \mathrm{H}_{2} \mathrm{O}$ & $\mathrm{O}_{\mathrm{C}}$ & 61 \\
\hline$(2-h e p \mathrm{H})\left(\mathrm{NH}_{4}\right)\left[\left\{\mathrm{Cu}\left(\mathrm{H}_{2} \mathrm{O}\right)_{2}(2-h e p)\right\}_{2} \mathrm{~V}_{10} \mathrm{O}_{28}\right] \cdot 4 \mathrm{H}_{2} \mathrm{O}$ & $\mathrm{O}_{\mathrm{C}}$ & $\begin{array}{l}\text { This } \\
\text { work }\end{array}$ \\
\hline$\left[\mathrm{Cu}(2-\mathrm{amp})_{2}\left(\mathrm{H}_{2} \mathrm{O}\right)\right]_{2} \mathrm{H}_{2} \mathrm{~V}_{10} \mathrm{O}_{28} \cdot 4 \mathrm{H}_{2} \mathrm{O}$ & $\mathrm{O}_{\mathrm{C}}$ & 61 \\
\hline$\left(\mathrm{H}_{3} \mathrm{O}\right)_{2}\left[\left\{\mathrm{Cu}(\mathrm{en})_{2}\left(\mathrm{H}_{2} \mathrm{O}\right)\right\}_{2} \mathrm{~V}_{10} \mathrm{O}_{28}\right] \cdot 3 \mathrm{H}_{2} \mathrm{O}$ & $\mathrm{O}_{\mathrm{C}}, \mathrm{O}_{\mathrm{D}}$ & 67 \\
\hline$\left[\left\{\mathrm{Cu}(e n)_{2}\right\}_{3}\left(\mathrm{~V}_{10} \mathrm{O}_{28}\right)\right] \cdot 6 \mathrm{H}_{2} \mathrm{O}$ & $\mathrm{O}_{\mathrm{C}}, \mathrm{O}_{\mathrm{D}}$ & 67 \\
\hline$\left[\mathrm{Zn}_{2}\left(\mathrm{H}_{2} \mathrm{O}\right)_{14}\left(\mathrm{~V}_{10} \mathrm{O}_{28}\right)\right] \cdot \mathrm{H}_{2} p p z$ & $\mathrm{O}_{\mathrm{D}}$ & 68 \\
\hline$\left[\mathrm{Zn}\left(\mathrm{H}_{2} \mathrm{O}\right)_{6}\right]\left[\mathrm{Zn}_{2} \mathrm{~V}_{10} \mathrm{O}_{28}\left(\mathrm{H}_{2} \mathrm{O}\right)_{10}\right] \cdot 6 \mathrm{H}_{2} \mathrm{O}$ & $\mathrm{O}_{\mathrm{F}}$ & 69 \\
\hline$\left[\mathrm{Zn}(e n)_{2}\right]_{3}\left[\mathrm{~V}_{10} \mathrm{O}_{28}\right] \cdot 5 \mathrm{H}_{2} \mathrm{O}$ & $\mathrm{O}_{\mathrm{C}}$ & 70 \\
\hline$\left[\mathrm{Zn}(\mathrm{im})_{2}(\mathrm{DMF})_{2}\right]_{2}\left[\mathrm{H}_{2} \mathrm{~V}_{10} \mathrm{O}_{28}\right] \cdot \mathrm{im} \cdot \mathrm{DMF}$ & $\mathrm{O}_{\mathrm{C}}$ & 71 \\
\hline$\left\{\left[\mathrm{Zn}_{3}(t r z)_{3}\left(\mathrm{H}_{2} \mathrm{O}\right)_{4}(\mathrm{DMF})\right]_{2}\left[\mathrm{~V}_{10} \mathrm{O}_{28}\right] \cdot 4 \mathrm{H}_{2} \mathrm{O}\right\}_{\mathrm{n}}$ & $\mathrm{O}_{\mathrm{C}}$ & 71 \\
\hline$(2-h e p H)_{2}\left[\left\{\mathrm{Mn}\left(\mathrm{H}_{2} \mathrm{O}\right)_{5}\right\}_{2} \mathrm{~V}_{10} \mathrm{O}_{28}\right] \cdot 4 \mathrm{H}_{2} \mathrm{O}$ & $\mathrm{O}_{\mathrm{F}}$ & 72 \\
\hline$\left\{\left[\mathrm{Mn}(\mathrm{mim})_{4}\right]_{2}\left[\mathrm{H}_{2} \mathrm{~V}_{10} \mathrm{O}_{28}\right]\right\}$ & $\mathrm{O}_{\mathrm{C}}, \mathrm{O}_{\mathrm{F}}$ & 73 \\
\hline$\left(\mathrm{NMe}_{4}\right)_{2}\left[\left\{\mathrm{Mn}\left(\mathrm{H}_{2} \mathrm{O}\right)_{5}\right\}_{2} \mathrm{~V}_{10} \mathrm{O}_{28}\right] \cdot 5 \mathrm{H}_{2} \mathrm{O}$ & $\mathrm{O}_{\mathrm{F}}$ & 76 \\
\hline$\left[\mathrm{NH}_{3} \mathrm{C}\left(\mathrm{CH}_{2} \mathrm{OH}\right)_{3}\right]_{2}\left[\left\{\mathrm{Mn}\left(\mathrm{H}_{2} \mathrm{O}\right)_{5}\right\}_{2} \mathrm{~V}_{10} \mathrm{O}_{28}\right] \cdot 2 \mathrm{H}_{2} \mathrm{O}$ & $\mathrm{O}_{\mathrm{F}}$ & 76 \\
\hline$\left.[\mathrm{Ag}(b t x)\}_{4} \mathrm{H}_{2} \mathrm{~V}_{10} \mathrm{O}_{28}\right] \cdot 2 \mathrm{H}_{2} \mathrm{O}$ & $\mathrm{O}_{\mathrm{C}}$ & 74 \\
\hline$\left[\left\{\mathrm{Na}_{3}\left(\mathrm{H}_{2} \mathrm{O}\right)_{8}\left(\mu_{2}-\mathrm{H}_{2} \mathrm{O}\right)_{6} \mathrm{Ag}_{2}\right\} \mathrm{HV}_{10} \mathrm{O}_{28}\right] \cdot 6 \mathrm{H}_{2} \mathrm{O}$ & $\mathrm{O}_{\mathrm{C}}, \mathrm{O}_{\mathrm{G}}$ & 75 \\
\hline$(2-h e p \mathrm{H})_{2}\left[\left\{\mathrm{Co}\left(\mathrm{H}_{2} \mathrm{O}\right)_{5}\right\}_{2} \mathrm{~V}_{10} \mathrm{O}_{28}\right] \cdot 4 \mathrm{H}_{2} \mathrm{O}$ & $\mathrm{O}_{\mathrm{F}}$ & $\begin{array}{l}\text { This } \\
\text { work }\end{array}$ \\
\hline
\end{tabular}

${ }^{a}$ As in Scheme 1. Abbreviations: $2,2^{\prime}$-bipy $-2,2^{\prime}$-bipyridine, $b t x-1,4-$ bis(triazol-1-ylmethyl)benzene, $p p z$ - piperazine, $p z$ - pyrazole, im - imidazole, mim - 1-methylimidazole, trz - 1,2,4-triazole, en - ethylenediamine, $a m p-2$-(aminomethyl)pyridine, 2-hep = 2-hydroxyethylpyridine, $L-5,5,7,12,12,14$-hexamethyl-1,4,8,11-tetraazacyclotetradecane.

possible to isolate only two complexes of decavanadate, and even they differed in the coordination mode of decavanadate and in the structure of the coordinated transition metal. Table 1 summarizes 22 compounds where decavanadate coordinates to transition metal cations. There are ten $\mathrm{Cu}^{\mathrm{II}}$, four $\mathrm{Zn}^{\mathrm{II}}$, four $\mathrm{Mn}^{\mathrm{II}}$ and two $\mathrm{Ag}^{\mathrm{I}}$ complexes. Compound $\mathbf{V}_{\mathbf{1 0}} \mathrm{Co}$ is the first complex of decavanadate involving $\mathrm{Co}^{\mathrm{II}}$. There are about 100 salts of decavanadate and some of them contain a transition metal complex in the cationic part, including the $\left[\mathrm{Co}\left(\mathrm{H}_{2} \mathrm{O}\right)_{6}\right]^{2+}$ complex cation. ${ }^{62 a-c}$ Therefore, in general it is still not clear what conditions are required for decavanadate to act as a ligand.

\subsection{Crystal structures}

The structure solution and refinement details for compounds $\mathbf{V}_{\mathbf{1 0}} \mathbf{C u}$ and $\mathbf{V}_{\mathbf{1 0}} \mathrm{Co}$ are summarized in Table 2. The crystal structure refinement of $\mathbf{V}_{\mathbf{1 0}} \mathbf{C u}$ revealed the presence of the complex anion $\left[\left\{\mathrm{Cu}\left(\mathrm{H}_{2} \mathrm{O}\right)_{2}(2-h e p)\right\}_{2} \mathrm{~V}_{10} \mathrm{O}_{28}\right]^{2-}$ that has been already reported (Fig. 1). ${ }^{61}$ The decavanadate anion $\left[\mathrm{V}_{10} \mathrm{O}_{28}\right]^{6-}$ is a bridging ligand between two $\left\{\mathrm{Cu}\left(\mathrm{H}_{2} \mathrm{O}\right)_{2}(2-h e p)\right\}^{2+}$ fragments and binds to the $\mathrm{Cu} 1$ atom through oxygen atom $\mathrm{O} 12\left(\mathrm{O}_{\mathrm{C}}\right.$ in Scheme 1$)$ at $1.9612(8) \AA$. The organic ligand is chelating the $\mathrm{Cu} 1$ atom by the $\mathrm{N}$ atom of the pyridine ring [N1-Cu1 1.9802(11) $\AA$ ] and the O atom of the hydroxyl group [O13-Cu1 1.9857(9) Å]. The tetragonal pseudoplane around the atom $\mathrm{Cu} 1$ is completed by a water molecule [O15-Cu1 1.9824(10) Å]; the water molecule in the axial position completes the pyramidal geometry [O14-Cu1 2.2860(10) $\AA$ ].

The closest contact in the trans position towards this water molecule is oxygen atom $\mathrm{O} 8$ of $\left[\mathrm{V}_{10} \mathrm{O}_{28}\right]^{6-}\left(\mathrm{O}_{\mathrm{G}}\right.$ in Scheme 1$)$. 
Table 2 Crystallographic and refinement data for compounds $\mathbf{V}_{\mathbf{1 0}} \mathbf{C u}$ and $\mathbf{V}_{\mathbf{1 0}} \mathrm{Co}$

\begin{tabular}{|c|c|c|}
\hline & $\mathrm{V}_{10} \mathrm{Cu}$ & $\mathrm{V}_{10} \mathrm{Co}$ \\
\hline Empirical formula & $\mathrm{V}_{10} \mathrm{Cu}_{2} \mathrm{O}_{39} \mathrm{C}_{21} \mathrm{H}_{48} \mathrm{~N}_{4}$ & $\mathrm{~V}_{10} \mathrm{Co}_{2} \mathrm{O}_{44} \mathrm{C}_{14} \mathrm{H}_{48} \mathrm{~N}_{2}$ \\
\hline$M_{\mathrm{r}}$ & 1605.02 & 1575.80 \\
\hline Temperature $(\mathrm{K})$ & 100 & 100 \\
\hline$a(\AA)$ & 27.0345(15) & $9.4219(5)$ \\
\hline$b(\AA)$ & $9.9170(5)$ & $11.2451(6)$ \\
\hline$\beta\left(^{\circ}\right)$ & 119.341(5) & $75.1180(17)$ \\
\hline$\gamma\left({ }^{\circ}\right)$ & & $66.3817(17)$ \\
\hline$V\left(\AA^{3}\right)$ & $4810.9(5)$ & $1117.66(11)$ \\
\hline$Z$ & 4 & 1 \\
\hline Radiation type & Mo K $\alpha$ & $\mathrm{Cu} \mathrm{K} \alpha$ \\
\hline$\mu\left(\mathrm{mm}^{-1}\right)$ & 2.82 & 23.51 \\
\hline Absorption correction & Multi-scan & Multi-scan \\
\hline \multirow[t]{3}{*}{ Index ranges } & $h=-44 \rightarrow 44$ & $h=-11 \rightarrow 11$ \\
\hline & $k=-16 \rightarrow 16$ & $k=-13 \rightarrow 13$ \\
\hline & $l=-33 \rightarrow 33$ & $l=-12 \rightarrow 14$ \\
\hline No. of measured, independent and observed $[I>2 s(I)]$ reflections & $343398,11216,9986$ & $16530,4079,3882$ \\
\hline$R_{\text {int }}$ & 0.062 & 0.127 \\
\hline No. of reflections, parameters, restraints & $11216,421,9$ & $4079,337,20$ \\
\hline Goodness-of-fit on $F^{2}$ & 1.10 & 1.16 \\
\hline$R\left[F^{2}>2 s\left(F^{2}\right)\right]$ & 0.024 & 0.098 \\
\hline $\mathrm{w} R\left(F^{2}\right)$ & 0.071 & 0.222 \\
\hline Largest diff. peak and hole & 0.79 e $\AA^{-3},-0.65$ e $\AA^{-3}$ & 1.79 e $\AA^{-3},-1$ e $\AA^{-3}$ \\
\hline
\end{tabular}

The short distance O8-Cu1 $2.889 \AA$ Andicates some weak attraction. The crystal structure of $\mathbf{V}_{\mathbf{1 0}} \mathbf{C u}$ differs from the previously described one ${ }^{61}$ in the presence of the $\mathrm{NH}_{4}{ }^{+}$cation that was confirmed by elemental analysis and IR spectroscopy.

The asymmetric unit of $\mathbf{V}_{\mathbf{1 0}} \mathbf{C o}$ contains one half of the centrosymmetric anion $\left[\left\{\mathrm{Co}\left(\mathrm{H}_{2} \mathrm{O}\right)_{5}\right\}_{2} \mathrm{~V}_{10} \mathrm{O}_{28}\right]^{2-}$ (Fig. 1), one molecule of $(2-h e p \mathrm{H})^{+}$balancing its charge and two water molecules of crystallization. The decavanadate anion $\left[\mathrm{V}_{10} \mathrm{O}_{28}\right]^{6-}$ is acting as a bridging ligand for two $\left\{\mathrm{Co}\left(\mathrm{H}_{2} \mathrm{O}\right)_{5}\right\}^{2+}$ fragments. The slightly irregular octahedral coordination sphere of the Co1 atom is completed by one oxygen atom $\mathrm{O} 1$ coming from the terminal $\mathrm{V}=\mathrm{O}$ group of the decavanadate (atom $\mathrm{O}_{\mathrm{F}}$ in Scheme 1). Such a coordination fashion is not unknown and was already reported for manganese(III) ${ }^{72,76}$ and zinc(II) derivatives. ${ }^{68,69}$ The bond length O1-Co1 2.089(3) ̊ indicates a relatively strong coordination bond of decavanadate to the metal centre. The bond lengths of the Co1 atom and oxygen atoms of the coordinated water molecules are in the range of $2.105-2.115 \AA$ for the equatorial ligands and 2.057(4) $\AA$ for the Co1-O15 bond of the water molecule in the trans position towards the decavanadate ligand.

The supramolecular structure of $\mathbf{V}_{\mathbf{1 0}} \mathbf{C o}$ is stabilized by a rich network constructed from hydrogen bonds in which all the individual components are involved. Due to the presence of $\left\{\mathrm{Co}\left(\mathrm{H}_{2} \mathrm{O}\right)_{5}\right\}^{2+}$ fragments the most prominent hydrogen bonds are formed between the adjacent $\left[\left\{\mathrm{Co}\left(\mathrm{H}_{2} \mathrm{O}\right)_{5}\right\}_{2} \mathrm{~V}_{10} \mathrm{O}_{28}\right]^{2-}$ anions. Three oxygen atoms of the decavanadate $\mathrm{O} 5, \mathrm{O} 6$ and $\mathrm{O} 11$ are connected with hydrogen bonds to three water molecules of $\left\{\mathrm{Co}\left(\mathrm{H}_{2} \mathrm{O}\right)_{5}\right\}^{2+}$ at contact distances $\mathrm{O} 5 \cdots \mathrm{O} 172.636 \AA$, O6 $\cdots \mathrm{O} 172.636 \AA$ and $\mathrm{O} 11 \cdots \mathrm{O} 152.744 \AA$.

\subsection{Solution studies}

3.3.1 Stability in a buffer solution. For the solutions studies $1 \mathrm{mM}$ decavanadate solutions of $\mathbf{V}_{\mathbf{1 0}}, \mathbf{V}_{\mathbf{1 0}} \mathbf{C u}$ and $\mathbf{V}_{\mathbf{1 0}} \mathbf{C o}$ were firstly prepared in a medium containing $0.1 \mathrm{M}$ MES buffer and $0.5 \mathrm{M} \mathrm{NaCl}$ at $\mathrm{pH}=5.8$. These conditions were used to simulate the environment of protein crystallization where usually higher buffer concentrations and high ionic strengths are necessary. The acidic regime is preferred to ensure that the protein is positively charged and may therefore more profoundly interact with negatively charged POMs. The ${ }^{51} \mathrm{~V}$ NMR spectra of the given solutions are shown in Fig. 2. In the spectrum of $\mathbf{V}_{\mathbf{1 0}}$ the expected distribution of vanadium into several species can be observed. Due to hydrolysis, the equilibrated species include not only the originally employed decavanadate $(-422.5,-498.2$ and $-513.8 \mathrm{ppm})$, but also monovanadate $\mathrm{H}_{2} \mathrm{VO}_{4}{ }^{-}\left(\mathrm{V}_{1},-558.5 \mathrm{ppm}\right)$, divanadate $\mathrm{H}_{2} \mathrm{~V}_{2} \mathrm{O}_{7}{ }^{2-}\left(\mathrm{V}_{2},-571.2 \mathrm{ppm}\right)$, tetravanadate $\mathrm{V}_{4} \mathrm{O}_{12}{ }^{4-}$ $\left(\mathrm{V}_{4},-575.0 \mathrm{ppm}\right)$ and pentavanadate $\mathrm{V}_{5} \mathrm{O}_{15}{ }^{5-}\left(\mathrm{V}_{5},-583.0 \mathrm{ppm}\right)$. However, due to the high ionic strength decavanadate is still the dominant species and consumes about $80 \%$ of $\mathrm{V}^{\mathrm{V}}$ present in the solution.

The spectra of $\mathbf{V}_{\mathbf{1 0}} \mathbf{C u}$ and $\mathbf{V}_{\mathbf{1 0}} \mathbf{C o}$ exhibit only peaks that can be assigned to vanadium atoms arising from decavanadate: $-422.3,-496.9$ and $-511.9 \mathrm{ppm}$ for $\mathbf{V}_{10} \mathrm{Cu}$ and -422.3 and $-495.9 \mathrm{ppm}$ (broad peak) for $\mathbf{V}_{\mathbf{1 0}} \mathbf{C o}$. This is the first indication that the complex anions stay intact and do not dissociate off the $\mathrm{Cu}$ (II) and $\mathrm{Co}(\mathrm{II})$ centres. As a matter of fact, the presence of free decavanadate would evoke vanadate self-condensation reactions and the overall picture of the present species should be similar 

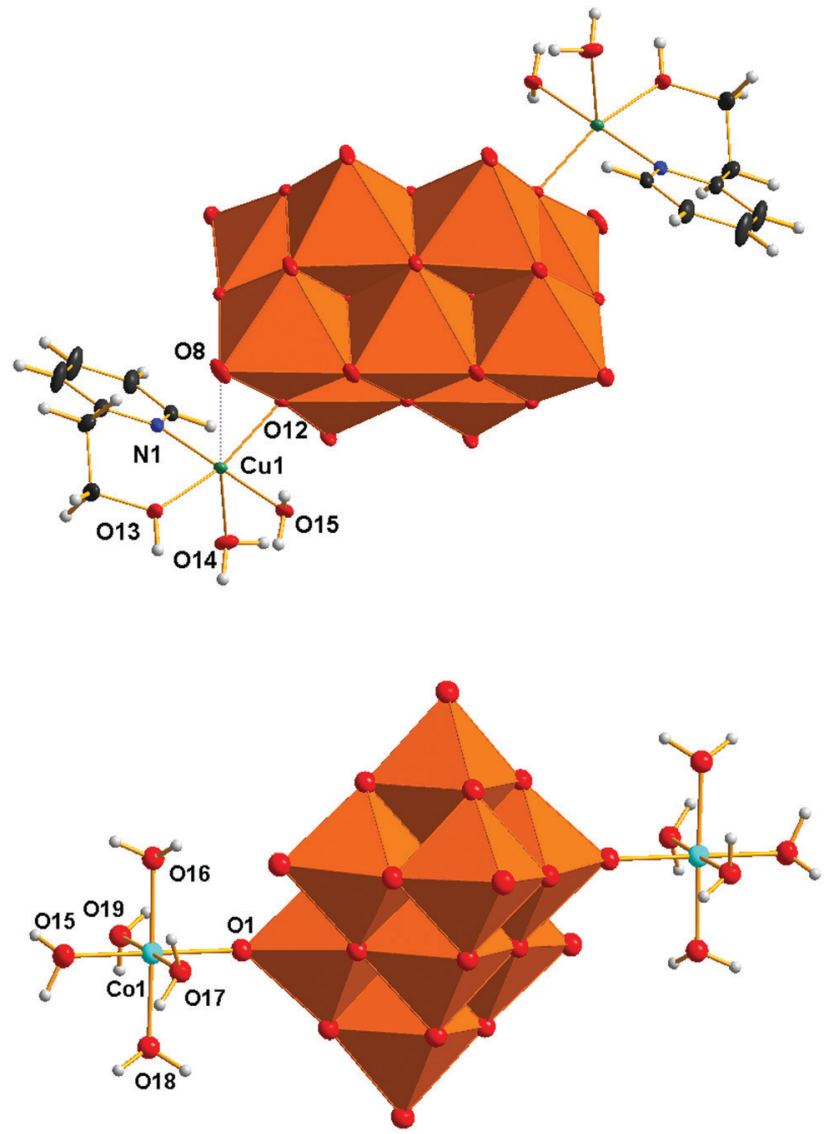

Fig. 1 Molecular structures of the anions $\left[\left\{\mathrm{Cu}\left(\mathrm{H}_{2} \mathrm{O}\right)_{2}(2-h e p)\right\}_{2} \mathrm{~V}_{10} \mathrm{O}_{28}\right]^{2-}$ $\left(\mathrm{V}_{\mathbf{1 0}} \mathrm{Cu}\right)$ and $\left[\left\{\mathrm{Co}\left(\mathrm{H}_{2} \mathrm{O}\right)_{5}\right\}_{2} \mathrm{~V}_{10} \mathrm{O}_{28}\right]^{2-}\left(\mathrm{V}_{\mathbf{1 0}} \mathrm{Co}\right)$ as revealed by $\mathrm{X}$-ray crystallography showing atom labelling. Colour code: orange octahedra $\left\{\mathrm{VO}_{6}\right\}$, green $\mathrm{Cu}$, light blue $\mathrm{Co}$, blue $\mathrm{N}$, red $\mathrm{O}$, black $\mathrm{C}$, gray $\mathrm{H}$. Ellipsoids are displayed at a $30 \%$ probability level.

to that of $\mathbf{V}_{\mathbf{1 0}}$. Next, similar to Schwendt et al. ${ }^{61}$ we observed significant movement of the high-field signal of the $\mathrm{V}_{\mathrm{C}}$ atom in $\mathbf{V}_{\mathbf{1 0}} \mathbf{C u}$ to $-511.9 \mathrm{ppm}$ compared to $-513.8 \mathrm{ppm}$ in $\mathbf{V}_{\mathbf{1 0}}$, and the signal of the $\mathrm{V}_{\mathrm{B}}$ atom is shifted by $1.3 \mathrm{ppm}$. For $\mathbf{V}_{\mathbf{1 0}} \mathbf{C o}$, the shift of the peak is much more obvious and instead of two independent signals for $\mathrm{V}_{\mathrm{B}}$ and $\mathrm{V}_{\mathrm{C}}$ atoms we observe only a broad peak with the maximum at $-495.9 \mathrm{ppm}$ having a high-field shoulder. Based on peak integration, the integral intensities of the two present signals are in the ratio $2: 8$. In addition, significant peak broadening of the individual signals was observed (Table 3). This can be explained by at least two factors. Firstly, vanadates usually provide narrower lines in comparison to common vanadium(v) complexes because of higher symmetry (i.e. $D_{2 \mathrm{~h}}$ for ideal $\left[\mathrm{V}_{10} \mathrm{O}_{28}\right]^{6-}$ ). Thus, peak broadening originates in the decrease of symmetry of the coordinated decavanadates. It is also important to note that for $\mathbf{V}_{\mathbf{1 0}}$ Co the low field signal is broadened by only $10 \%$ in comparison to free decavanadate, while the second signal is broader by more than $220 \%$ compared to the sum of individual signals of $V_{B}$ and $V_{C}$ in $\mathbf{V}_{\mathbf{1 0}}$. This difference is naturally caused by the fact that the $\mathrm{V}_{\mathrm{C}}$ atoms are the closest ones to the $\mathrm{Co}$ (II) atom and the inner $\mathrm{V}_{\mathrm{A}}$ atoms are less affected by the coordination. The compound $\mathbf{V}_{\mathbf{1 0}} \mathbf{C u}$ formed a cloudy precipitate in the
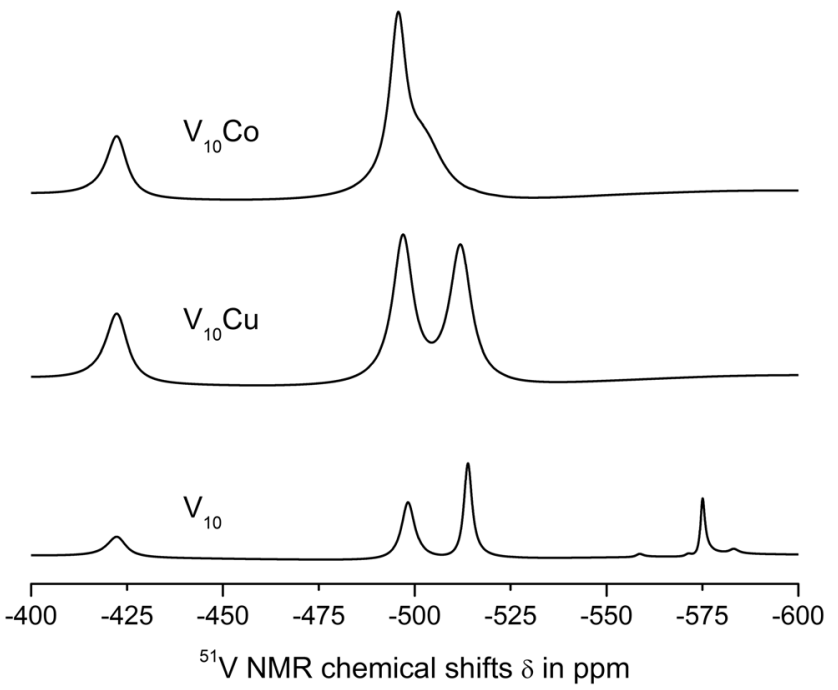

Fig. $2{ }^{51} \mathrm{~V}$ NMR spectra of $1 \mathrm{mM}$ aqueous solutions of $\mathbf{V}_{\mathbf{1 0}}, \mathbf{V}_{\mathbf{1 0}} \mathbf{C u}$ and $\mathrm{V}_{10} \mathrm{Co}$ in $0.1 \mathrm{M} \mathrm{MES}$ buffer, $0.5 \mathrm{M} \mathrm{NaCl}$ at $\mathrm{pH}=5.8$.

buffer solution which might have also influenced the peaks' width, but despite this, similar peak broadening as for $\mathbf{V}_{\mathbf{1 0}} \mathbf{C o}$ was observed $-14 \%$ and $200 \%$, respectively. This leads to the conclusion that the peak coalescence is a consequence of its coordination to the $\mathrm{Cu}(\mathrm{II})$ center and not the presence of a precipitate. However, we excluded $\mathbf{V}_{\mathbf{1 0}} \mathbf{C u}$ from further examination to prevent misinterpretation of protein interaction experiments.

On the other hand, peak broadening may also originate in the presence of paramagnetic centres $\mathrm{Cu}(\mathrm{II})\left(\mathrm{d}^{9}\right)$ and $\mathrm{Co}(\mathrm{II})\left(\mathrm{d}^{7}\right)$. The experience has shown, however, that if an extraneous paramagnetic species interferes in a ${ }^{51} \mathrm{~V}$ NMR experiment, this manifests itself also in a lower signal-to-noise ratio and uneven lines (this was not the case).

At $\mathrm{pH}=8.0(0.1 \mathrm{M}$ MES, $0.5 \mathrm{NaCl})$ profound decomposition of $\mathbf{V}_{\mathbf{1 0}}$ into lower vanadates was observed, $\mathbf{V}_{\mathbf{1 0}} \mathbf{C u}$ dissociated off the $\mathrm{Cu}(\mathrm{II})$ complex cation, while $\mathbf{V}_{\mathbf{1 0}} \mathbf{C o}$ was still the only species present (see Fig. S1 and Table S1, ESI $\dagger$ ).

3.3.2 Interaction of decavanadates with thaumatin, lysozyme and proteinase $K$. The interaction of $\mathbf{V}_{\mathbf{1 0}}$ and $\mathbf{V}_{\mathbf{1 0}} \mathrm{Co}$ $(1 \mathrm{mM})$ with model proteins thaumatin $(10 \mu \mathrm{M})$, lysozyme $(10 \mu \mathrm{M})$ and proteinase $\mathrm{K}(3.5 \mu \mathrm{M})$ was inspected by ${ }^{51} \mathrm{~V}$ NMR

Table 3 The ${ }^{51} \mathrm{~V}$ NMR parameters of peaks in the spectra of solutions of $\mathrm{V}_{\mathbf{1 0}}, \mathrm{V}_{\mathbf{1 0}} \mathrm{Cu}$ and $\mathrm{V}_{\mathbf{1 0}} \mathrm{Co}$ in 0.1 M MES, 0.5 M NaCl at $\mathrm{pH}=5.8$. The chemical shifts are given in ppm (upper) and the linewidths at half-height in $\mathrm{Hz}$ (lower). The linewidths are not given for species with concentrations $<5 \%$

\begin{tabular}{|c|c|c|c|c|c|c|c|}
\hline & \multicolumn{3}{|c|}{$\underline{\mathrm{H}_{x} \mathrm{~V}_{10} \mathrm{O}_{28}{ }^{(6-x)-}}$} & \multirow[b]{2}{*}{$\mathrm{H}_{2} \mathrm{VO}_{4}^{-}$} & \multirow[b]{2}{*}{$\mathrm{H}_{2} \mathrm{~V}_{2} \mathrm{O}_{7}^{2-}$} & \multirow[b]{2}{*}{$\mathrm{V}_{4} \mathrm{O}_{12}{ }^{4-}$} & \multirow[b]{2}{*}{$\mathrm{V}_{5} \mathrm{O}_{15}{ }^{5-}$} \\
\hline & $\mathrm{V}_{\mathrm{A}}$ & $\mathrm{V}_{\mathrm{B}}$ & $\mathrm{V}_{\mathrm{C}}$ & & & & \\
\hline$V_{10}$ & $\begin{array}{r}-422.5 \\
636.22\end{array}$ & $\begin{array}{l}-498.2 \\
483.86\end{array}$ & $\begin{array}{l}-513.8 \\
309.16\end{array}$ & -558.5 & -571.2 & $\begin{array}{c}-575.0 \\
176.77\end{array}$ & -583.0 \\
\hline $\mathrm{V}_{10} \mathrm{Cu}$ & $\begin{array}{c}-422.3 \\
727.51\end{array}$ & $\begin{array}{l}-496.9 \\
775.17\end{array}$ & $\begin{array}{l}-511.9 \\
806.75\end{array}$ & - & - & - & - \\
\hline $\mathrm{V}_{10} \mathrm{Co}$ & $\begin{array}{c}-422.3 \\
702.38\end{array}$ & $\begin{array}{l}-495.9 \\
1794.05\end{array}$ & & - & - & - & - \\
\hline
\end{tabular}

${ }^{a}$ The linewidth was calculated from the half-height for the low-field and high-field components of the merged broad signal. 

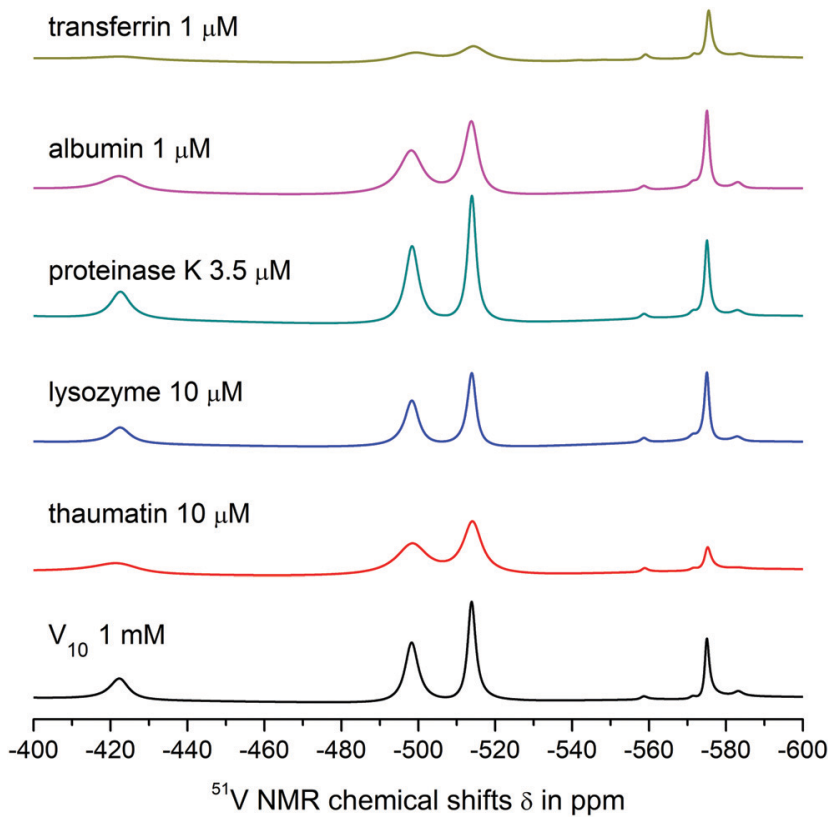

Fig. $3{ }^{51} \mathrm{~V}$ NMR spectra showing interactions of $1 \mathrm{mM}$ aqueous solutions of $\mathbf{V}_{\mathbf{1 0}}$ with model proteins under given concentrations in $0.1 \mathrm{M} \mathrm{MES}$ buffer, $0.5 \mathrm{M} \mathrm{NaCl}$ at $\mathrm{pH}=5.8$. The black line represents the spectrum of the referent $\mathbf{V}_{\mathbf{1 0}} \mathrm{Co}$ and the coloured lines show the spectra of solutions of $\mathrm{V}_{\mathbf{1 0}} \mathrm{Co}$ in the presence of different proteins at given concentrations.

spectroscopy in $0.1 \mathrm{MES}$ buffer, $0.5 \mathrm{M} \mathrm{NaCl}$ at $\mathrm{pH}=5.8$ one hour after careful addition of the protein solution to the solution of POMs (Fig. 3 and 4). Table 4 summarizes the data on chemical shifts and linewidths at half-height for the observed peaks. During the experiments, a peak movement larger than $\pm 1 \mathrm{ppm}$ was not observed indicating that no changes in protonation

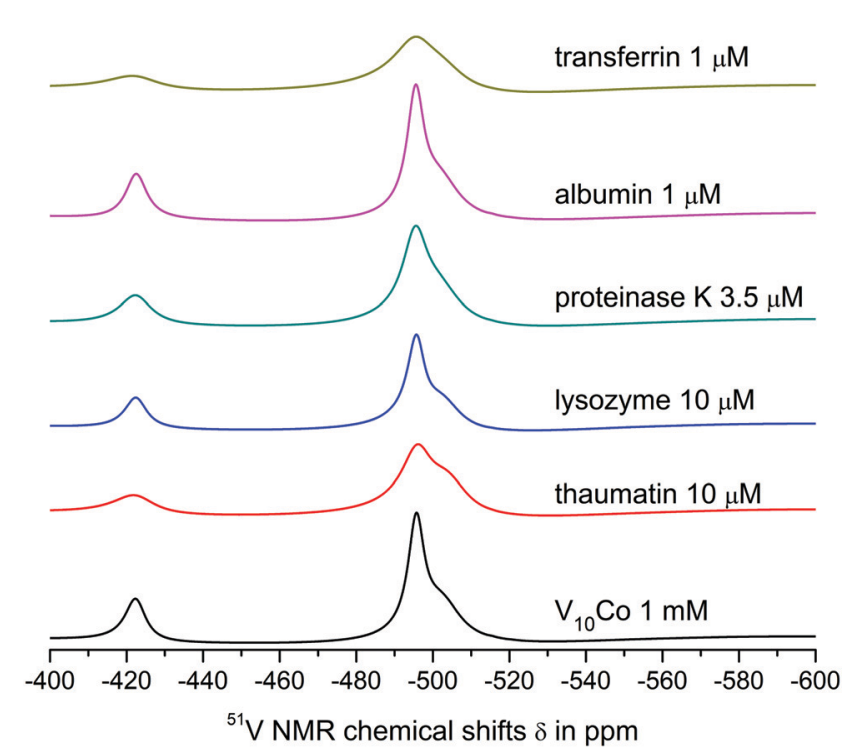

Fig. $4{ }^{51} \mathrm{~V}$ NMR spectra showing interactions of $1 \mathrm{mM}$ aqueous solutions of $\mathrm{V}_{10} \mathrm{Co}$ with model proteins under given concentrations in $0.1 \mathrm{M}$ MES buffer, $0.5 \mathrm{M} \mathrm{NaCl}$ at $\mathrm{pH}=5.8$. The black line represents the spectrum of the referent $\mathbf{V}_{\mathbf{1 0}} \mathrm{Co}$ and the coloured lines show the spectra of solutions of $\mathrm{V}_{\mathbf{1 0}} \mathrm{Co}$ in the presence of different proteins at given concentrations.
Table 4 The ${ }^{51} \mathrm{~V}$ NMR parameters of peaks in the spectra of solutions of $V_{10}$ and $V_{10} C_{0}$ in the presence of model proteins $\left(c_{V}=10 \mathrm{mM}, 0.1 \mathrm{M}\right.$ MES, $0.5 \mathrm{M} \mathrm{NaCl}, \mathrm{pH}=5.8$ ). The chemical shifts are given in ppm (upper) and the linewidths at half-height in $\mathrm{Hz}$ (lower)

\begin{tabular}{|c|c|c|c|c|c|}
\hline \multirow[b]{2}{*}{ Protein } & \multirow[b]{2}{*}{ Decavanadate } & \multicolumn{3}{|c|}{$\mathrm{H}_{x} \mathrm{~V}_{10} \mathrm{O}_{28}{ }^{(6-x)-}$} & \multirow[b]{2}{*}{$\mathrm{V}_{4} \mathrm{O}_{12}{ }^{4-}$} \\
\hline & & $\mathrm{V}_{\mathrm{A}}$ & $\mathrm{V}_{\mathrm{B}}$ & $\mathrm{V}_{\mathrm{C}}$ & \\
\hline \multirow[t]{2}{*}{ None } & $\mathbf{V}_{10}$ & -422.5 & -498.2 & -513.8 & -575.0 \\
\hline & $\mathrm{V}_{10} \mathrm{Co}$ & $\begin{array}{c}-422.3 \\
702.38\end{array}$ & $\begin{array}{l}-495.9 \\
1794.05^{a}\end{array}$ & & - \\
\hline \multirow[t]{2}{*}{ Thaumatin $10 \mu \mathrm{M}$} & $\mathbf{V}_{10}$ & $\begin{array}{l}-421.5 \\
1144.08\end{array}$ & $\begin{array}{l}-498.5 \\
1198.98\end{array}$ & $\begin{array}{l}-514.1 \\
746.33\end{array}$ & $\begin{array}{r}-575.2 \\
274.76\end{array}$ \\
\hline & $\mathrm{V}_{10} \mathrm{Co}$ & $\begin{array}{c}-421.8 \\
1265.82\end{array}$ & $\begin{array}{l}-495.9 \\
2254.31^{a}\end{array}$ & & - \\
\hline \multirow[t]{2}{*}{ Lysozyme $10 \mu \mathrm{M}$} & $\mathbf{V}_{10}$ & $\begin{array}{r}-422.5 \\
580.67\end{array}$ & $\begin{array}{l}-498.3 \\
530.95\end{array}$ & $\begin{array}{l}-4513.9 \\
342.1\end{array}$ & $\begin{array}{r}-575.0 \\
199.5\end{array}$ \\
\hline & $\mathrm{V}_{10} \mathrm{Co}$ & $\begin{array}{r}-422.4 \\
732.6\end{array}$ & $\begin{array}{l}-495.7 \\
1810.91^{a}\end{array}$ & & - \\
\hline \multirow[t]{2}{*}{ Proteinase $\mathrm{K} 3.5 \mu \mathrm{M}$} & $V_{10}$ & $\begin{array}{c}-422.6 \\
653.95\end{array}$ & $\begin{array}{l}-498.4 \\
510.83\end{array}$ & $\begin{array}{l}-513.9 \\
326.98\end{array}$ & $\begin{array}{r}-575.1 \\
194.65\end{array}$ \\
\hline & $\mathrm{V}_{10} \mathrm{Co}$ & $\begin{array}{c}-422.3 \\
977.23\end{array}$ & $\begin{array}{l}-495.6 \\
2041.13^{a}\end{array}$ & & - \\
\hline \multirow[t]{2}{*}{ Albumin $1 \mu \mathrm{M}$} & $\mathbf{V}_{10}$ & $\begin{array}{c}-422.3 \\
943.72\end{array}$ & $\begin{array}{l}-498.2 \\
851.65\end{array}$ & $\begin{array}{l}-513.8 \\
532.05\end{array}$ & $\begin{array}{l}-575.0 \\
192.97\end{array}$ \\
\hline & $\mathrm{V}_{10} \mathrm{Co}$ & $\begin{array}{r}-422.5 \\
709.7\end{array}$ & $\begin{array}{l}-495.6 \\
1629.61^{a}\end{array}$ & & - \\
\hline \multirow[t]{2}{*}{ Transferrin $1 \mu \mathrm{M}$} & $\mathbf{V}_{10}$ & $\begin{array}{c}-422.6 \\
967.87\end{array}$ & $\begin{array}{l}-499.5 \\
-\end{array}$ & $\begin{array}{l}-513.8 \\
983.55\end{array}$ & $\begin{array}{r}-575.5 \\
230.59\end{array}$ \\
\hline & $\mathrm{V}_{10} \mathrm{Co}$ & $\begin{array}{c}-421.6 \\
1268.63\end{array}$ & $\begin{array}{l}-495.6 \\
2404.42^{a}\end{array}$ & & - \\
\hline
\end{tabular}

${ }^{a}$ The linewidth was calculated from the half-height for the low-field and high-field components of the merged broad signal.

occurred. Table 4 includes data only for decavanadates and $\left[\mathrm{V}_{4} \mathrm{O}_{12}\right]^{4-}$ as peaks corresponding to other vanadates had integral intensities $<5 \%$. Importantly, no visible reduction of vanadium(v) was recognized after 1 week of standing solutions.

Both $\mathbf{V}_{\mathbf{1 0}}$ and $\mathbf{V}_{\mathbf{1 0}}$ Co bind strongly to thaumatin resulting in significant peak broadening. In the case of lysozyme, very weak binding to $\mathbf{V}_{\mathbf{1 0}}$ may be deduced from slightly broadened higher-field peaks, but no obvious interaction was observed for $\mathbf{V}_{\mathbf{1 0}}$ Co. Finally, proteinase $\mathrm{K}$ seemed not to interact with free decavanadate, but binds strongly to $\mathbf{V}_{\mathbf{1 0}} \mathbf{C o}$. In this case we used about 3 times lower protein concentration; therefore, after extrapolation of the data it can be assumed that the binding of $\mathbf{V}_{\mathbf{1 0}} \mathbf{C o}$ to proteinase $\mathrm{K}$ is comparatively stronger than to thaumatin.

3.3.3 Interaction of decavanadates with human serum albumin and transferrin. Using the same experimental conditions, the interaction of $\mathbf{V}_{\mathbf{1 0}}$ and $\mathbf{V}_{\mathbf{1 0}} \mathbf{C o}$ with the main proteins present in human plasma, namely, human serum albumin $(1 \mu \mathrm{M})$ and transferrin $(1 \mu \mathrm{M})$ (Fig. 3, 4 and Table 4$)$, was also examined. Interestingly, free decavanadate $\mathbf{V}_{\mathbf{1 0}}$ binds strongly to albumin, but $\mathbf{V}_{\mathbf{1 0}} \mathbf{C o}$ does not interact. It seems that the $\mathrm{Co}(\mathrm{II})$ centers coordinated to $\mathrm{V}=\mathrm{O}$ groups of decavanadate occupy the binding sites for interaction of decavanadate with this protein and block the interaction. In fact, this was the only case where the interaction was observed only for the free decavanadate but not for the coordinated one. The interaction of $\mathrm{V}_{4} \mathrm{O}_{12}{ }^{4-}$ with human serum albumin is much weaker than that of decavanadate based on only about $10 \%$ increase in the peak width. 
The interaction of $\mathbf{V}_{\mathbf{1 0}}$ with transferrin is even stronger, and a significant binding to $\mathrm{V}_{4} \mathrm{O}_{12}{ }^{4-}$ was also observed. The shift of the peak corresponding to the $\mathrm{V}_{\mathrm{B}}$ atom of the decavanadate by $1 \mathrm{ppm}$ made it impossible to determine its half-height width. As expected, the presence of $\mathrm{Co}$ (II) causes extremely strong binding of $\mathbf{V}_{\mathbf{1 0}} \mathbf{C o}$ to transferrin, resulting in peak broadening comparable to that observed in the case of thaumatin, but at $100 \times$ lower protein concentration.

The stability of $\mathbf{V}_{\mathbf{1 0}} \mathbf{C o}, \mathbf{V}_{\mathbf{1 0}} \mathbf{C u}$ and potentially other coordinated decavanadates in the examined medium at $10 \mathrm{mM}$ total vanadium concentration, in line with the potential of functionalized decavanadates to interact with various proteins, open new possibilities for the investigation of decavanadate's effects in biological systems - for the first time without the side effects of the always present lower oligovanadates (decavanadate may be the only species present in multicomponent solvents). ${ }^{77}$ On the other hand, at physiological concentrations $\left(c_{\mathrm{V}}=1 \mu \mathrm{M}\right.$ and less), vanadate exists only as a monomeric species $\left(\mathrm{VO}_{2}{ }^{+}\right.$, $\mathrm{H}_{2} \mathrm{VO}_{4}{ }^{-}, \mathrm{HVO}_{4}{ }^{-}$depending on the $\left.\mathrm{pH}\right){ }^{32}$ We therefore checked the stability of $\mathbf{V}_{\mathbf{1 0}} \mathbf{C o}$ at $1 \mu \mathrm{M}$ concentration $(10 \mu \mathrm{M}$ total vanadium) by ${ }^{51} \mathrm{~V}$ NMR (Fig. S2, ESI $\dagger$ ). The chemical shifts corresponding to the decavanadate species $(-421.2,-497.9$ and -513.1) represent an undisturbed anion indicating that the Co(II) centers are no longer involved in coordination.

\section{Conclusions}

In this work, we showed that the complex anions $\left[\left\{\mathrm{Cu}\left(\mathrm{H}_{2} \mathrm{O}\right)_{2}\right.\right.$ (2-hep $\left.)\}_{2} \mathrm{~V}_{10} \mathrm{O}_{28}\right]^{2-}$ and $\left[\left\{\mathrm{Co}\left(\mathrm{H}_{2} \mathrm{O}\right)_{5}\right\}_{2} \mathrm{~V}_{10} \mathrm{O}_{28}\right]^{2-}$ involving coordinated decavanadate are stable in aqueous solution and do not decompose in the buffer solution compatible with proteins $(0.1 \mathrm{M} \mathrm{MES}, 0.5 \mathrm{NaCl})$ at $\mathrm{pH}=5.8$ making them promising candidates for biological studies. For the first time, an interaction between modified decavanadate and biomolecules without the participation of lower oligovanadates was performed. The pilot interaction studies with several proteins used in model protein crystallization research showed that $\mathbf{V}_{\mathbf{1 0}}$ and $\mathbf{V}_{\mathbf{1 0}} \mathrm{Co}$ bind to thaumatin, $\mathbf{V}_{\mathbf{1 0}}$ binds also to lysozyme and $\mathbf{V}_{\mathbf{1 0}} \mathbf{C o}$ binds to proteinase $\mathrm{K}$. As expected, $\mathbf{V}_{\mathbf{1 0}}$ interacts with human serum albumin and transferrin, but surprisingly $\mathbf{V}_{\mathbf{1 0}}$ Co exhibits high affinity to transferrin but does not interact with albumin. The isolation and structural characterization of the crystalline products is the ultimate goal necessary for more precise understanding of the interaction between POMs and proteins. It is expected that, in addition to electrostatic interaction of $\mathbf{V}_{\mathbf{1 0}}$ with proteins, the presence of heterometals may induce a complementary interaction - even a covalent bond - when the coordinated transition metal contains labile ligands such as water molecules (as in $\mathbf{V}_{\mathbf{1 0}} \mathbf{C o}$ and $\mathbf{V}_{\mathbf{1 0}} \mathbf{C u}$ ) or a vacant accessible coordination position (as in $\mathbf{V}_{\mathbf{1 0}} \mathbf{C u}$ ). Furthermore, both $\mathbf{V}_{\mathbf{1 0}} \mathbf{C u}$ and $\mathbf{V}_{\mathbf{1 0}} \mathbf{C o}$ contain biogenic transition metals that are known to interact with biomolecules to a great extent. In conclusion, the high potential of ligated decavanadate in medicinal chemistry and protein crystallography necessitates the challenging development of synthetic methods leading reliably to stable complexes of decavanadate (i.e. decavanadato complexes).

\section{Conflicts of interest}

There are no conflicts to declare.

\section{Acknowledgements}

This research was funded by the Austrian Science Fund (FWF): M2200 (LK) and P27534 (AR) and the University of Vienna. The authors are grateful to Dr Marek Bujdoš (Comenius University in Bratislava, Faculty of Natural Sciences, Institute of Laboratory Research on Geomaterials, Mlynská dolina, Ilkovičova 6, Bratislava, 84215, Slovakia) for elemental analyses and Ao. Univ.-Prof. Dr Markus Galanski (Universität Wien, Fakultät für Chemie, Institut für Anorganische Chemie, Währinger Straße 42, 1090 Wien, Austria) for great support with ${ }^{51} \mathrm{~V}$ NMR measurements.

\section{References}

1 M. T. Pope, Heteropoly and Isopoly Oxometalates, Springer-Verlag Berlin Heidelberg, 1983.

2 M. T. Pope, M. Sadakane and U. Kortz, Eur. J. Inorg. Chem., 2019, 340-342, DOI: 10.1002/ejic.201801543.

3 J. F. Keggin, Nature, 1933, 131, 908-909, DOI: 10.1038/ 131908b0.

4 M. T. Pope and A. Müller, Angew. Chem., Int. Ed. Engl., 1991, 30, 34-48, DOI: 10.1002/anie.199100341.

5 E. Coronado and C. J. Gómez-García, Chem. Rev., 1998, 98, 273-296, DOI: 10.1021/cr970471c.

6 Y.-F. Song and R. Tsunashima, Chem. Soc. Rev., 2012, 41, 7384-7402, DOI: 10.1039/c2cs35143a.

7 C. L. Hill and C. M. Prosser-McCartha, Coord. Chem. Rev., 1995, 143, 407-455, DOI: 10.1016/0010-8545(95)01141-B.

8 S.-S. Wang and G.-Y. Yang, Chem. Rev., 2015, 115, 4893-4962, DOI: 10.1021/cr500390v.

9 H. Lv, Y. V. Geletii, C. Zhao, J. W. Vickers, G. Zhu, Z. Luo, J. Song, T. Lian, D. G. Musaev and C. L. Hill, Chem. Soc. Rev., 2012, 41, 7572-7589, DOI: 10.1039/c2cs35292c.

10 N. Mizuno, K. Yamaguchi and K. Kamata, Coord. Chem. Rev., 2005, 249, 1944-1956, DOI: 10.1016/j.ccr.2004.11.019.

11 M. Sadakane and E. Steckhan, Chem. Rev., 1998, 98, 219-238, DOI: 10.1021/cr960403a.

12 N. I. Gumerova and A. Rompel, Nat. Rev. Chem., 2018, 2, 0112, DOI: 10.1038/s41570-018-0112.

13 C. Streb, K. Kastner and J. Tucher, Phys. Sci. Rev., 2019, 4, DOI: $10.1515 /$ psr-2017-0177.

14 C. Streb, Dalton Trans., 2012, 41, 1651-1659, DOI: 10.1039/ C1DT11220A.

15 J. Tucher, Y. Wu, L. C. Nye, I. Ivanovic-Burmazovic, M. M. Khusniyarov and C. Streb, Dalton Trans., 2012, 41, 9938-9943, DOI: 10.1039/C2DT30304C.

16 M. A. Al-Damen, J. M. Clemente-Juan, E. Coronado, C. Martí-Gastaldo and A. Gaita-Ariño, J. Am. Chem. Soc., 2008, 130, 8874-8875, DOI: 10.1021/ja801659m.

17 J. M. Clemente-Juan, E. Coronado and A. Gaita-Ariño, Chem. Soc. Rev., 2012, 41, 7464-7478, DOI: 10.1039/c2cs35205b. 
18 J. M. Clemente-Juan and E. Coronado, Coord. Chem. Rev., 1999, 193-195, 361-394, DOI: 10.1016/S0010-8545(99)00170-8.

19 J. T. Rhule, C. L. Hill, D. A. Judd and R. F. Schinazi, Chem. Rev., 1998, 98, 327-358, DOI: 10.1021/cr960396q.

20 L. S. Van Rompuy and T. N. Parac-Vogt, Curr. Opin. Biotechnol., 2019, 58, 92-99, DOI: 10.1016/j.copbio.2018.11.013.

21 D. A. Judd, J. H. Nettles, N. Nevins, J. P. Snyder, C. D. Liotta, J. Tang, J. Ermolieff, R. F. Schinazi and C. L. Hill, J. Am. Chem. Soc., 2001, 123, 886-897, DOI: 10.1021/ja001809e.

22 A. Bijelic, M. Aureliano and A. Rompel, Chem. Commun., 2018, 54, 1153-1169, DOI: 10.1039/c7cc07549a.

23 H.-J. Böhm, D. Banner, S. Bendels, M. Kansy, B. Kuhn, K. Müller, U. Obst-Sander and M. Stahl, ChemBioChem, 2004, 5, 637-643, DOI: 10.1002/cbic.200301023.

24 A. Bijelic, M. Aureliano and A. Rompel, Angew. Chem., Int. Ed., 2019, 58, 2980-2999, DOI: 10.1002/anie.201803868 and 10.1002/ange.201803868.

25 A. Bijelic and A. Rompel, Coord. Chem. Rev., 2015, 299, 22-38, DOI: 10.1016/j.ccr.2015.03.018.

26 A. Bijelic and A. Rompel, Acc. Chem. Res., 2017, 50, 1441-1448, DOI: 10.1021/acs.accounts.7b00109.

27 C. Molitor, A. Bijelic and A. Rompel, IUCrJ, 2017, 4, 734-740, DOI: $10.1107 / \mathrm{S} 2052252517012349$.

28 A. Bijelic and A. Rompel, ChemTexts, 2018, 4, 10, DOI: 10.1007/s40828-018-0064-1.

29 L. Pettersson, B. Hedman, A. M. Nennen and I. Andersson, Acta Chem. Scand., Ser. A, 1985, 39, 499-506, DOI: 10.3891/ acta.chem.scand.39a-0499.

30 H. Schmidt, I. Andersson, D. Rehder and L. Pettersson, Chem. - Eur. J., 2001, 7, 251-257, DOI: 10.1002/15213765(20010105)7:1 < 251::AID-CHEM251>3.0.CO;2-9.

31 A. S. Tracey, G. R. Willsky and E. S. Takeuchi, Vanadium. Chemistry, Biochemistry and Practical Applications, CRC Press, 2007.

32 D. Rehder, Bioinorganic Vanadium Chemistry, John Wiley \& Sons, Chichester, 2008.

33 D. Rehder, Metallomics, 2015, 7, 730-742, DOI: 10.1039/ c4mt00304g.

34 D. Rehder, Met. Ions Life Sci., 2013, 13, 139-169, DOI: 10.1007/978-94-007-7500-8-5.

35 D. C. Crans, J. J. Smee, E. Gaidamauskas and L. Yang, Chem. Rev., 2004, 104, 849-902, DOI: 10.1021/cr020607t.

36 T. Ueki, N. Yamaguchi, Y. Romaidi, Y. Isago and H. Tanahashi, Coord. Chem. Rev., 2015, 301-302, 300-308, DOI: 10.1016/j.ccr.2014.09.007.

37 J. C. Pessoa, S. Etcheverry and D. Gambino, Coord. Chem. Rev., 2015, 301-302, 24-48, DOI: 10.1016/j.ccr.2014.12.002.

38 D. Rehder, Future Med. Chem., 2012, 4, 1823-1827, DOI: 10.4155/fmc.12.103.

39 S. Y. Wong, R. W.-Y. Sun, N. P. Chung, C. L. Lin and C. M. Che, Chem. Commun., 2005, 3544-3546, DOI: 10.1039/B503535J.

40 S. Treviño, A. Díaz, E. Sánchez-Lara, B. L. Sanchez-Gaytan, J. M. Perez-Aguilar and E. González-Vergara, Biol. Trace Elem. Res., 2019, 56, 10893-10903, DOI: 10.1007/s12011-018-1540-6.

41 M. Aureliano and D. C. Crans, J. Inorg. Biochem., 2009, 103, 536-546, DOI: 10.1016/j.jinorgbio.2008.11.010.
42 M. Aureliano, Oxid. Med. Cell. Longevity, 2016, 6103457, DOI: $10.1155 / 2016 / 6103457$.

43 M. Aureliano and R. M. C. Gândara, J. Inorg. Biochem., 2005, 99, 979-985, DOI: 10.1016/j.jinorgbio.2005.02.024.

44 M. P. M. Marques, D. Gianolio, S. Ramos, L. A. E. B. D. Carvalho and M. Aureliano, Inorg. Chem., 2017, 56, 10893-10903, DOI: 10.1021/acs.inorgchem.7b01018.

45 T. Tiago, P. Martel, C. Gutiérrez-Merino and M. Aureliano, Biochim. Biophys. Acta, Gen. Subj., 2007, 1774, 474-480, DOI: 10.1016/j.bbapap.2007.02.004.

46 M. Aureliano, G. Fraqueza and C. A. Ohlin, Dalton Trans., 2013, 42, 11770-11777, DOI: 10.1039/C3DT50462J.

47 S. M. Ashraf Rajesh and S. Kaleem, Anal. Biochem., 1995, 230, 68-74, DOI: 10.1006/abio.1995.1439.

48 S. Lobert, N. Isern, B. S. Hennington and J. J. Correia, Biochemistry, 1994, 33, 6244-6252, DOI: 10.1021/bi00186a026.

49 R. L. Felts, T. J. Reilly and J. J. Tanner, J. Biol. Chem., 2006, 281, 30289-30298, DOI: 10.1074/jbc.M606391200.

50 J. H. Bae, E. D. Lew, S. Yuzawa, F. Tomé, I. Lax and J. Schlessinger, Cell, 2009, 138, 514-524, DOI: 10.1016/ j.cell.2009.05.028.

51 M. Zebisch, M. Krauss, P. Schäfer, P. Lauble and N. Sträter, Structure, 2013, 21, 1460-1475, DOI: 10.1016/j.str.2013.05.016.

52 M. Zebisch, M. Krauss, P. Schäfer and N. Sträter, J. Mol. Biol., 2012, 415, 288-306, DOI: 10.1016/j.jmb.2011.10.050.

53 P. A. Winkler, Y. Huang, W. Sun, J. Du and W. Lü, Nature, 2017, 552, 200-204, DOI: 10.1038/nature24674.

54 Bruker SAINT, V8.32B Copyright 2005-2015, Bruker AXS, 2013.

55 G. M. Sheldrick, $S A D A B S$, University of Göttingen, Germany, 1996.

56 G. M. Sheldrick, Acta Crystallogr., Sect. A: Found. Crystallogr., 2008, 64, 112-122, DOI: 10.1107/S0108767307043930.

57 G. M. Sheldrick, Acta Crystallogr., Sect. C: Struct. Chem., 2015, 71, 3-8, DOI: 10.1107/S2053229614024218.

58 O. V. Dolomanov, L. J. Bourhis, R. J. Gildea, J. A. K. Howard and H. Puschmann, J. Appl. Crystallogr., 2009, 42, 339-341, DOI: $10.1107 /$ S0021889808042726.

59 Diamond - Crystal and Molecular Structure Visualization. Crystal Impact - Dr H. Putz \& Dr K. Brandenburg GbR, Kreuzherrenstr. 102, 53227 Bonn, Germany. http://www. crystalimpact.com/diamond.

60 G. G. Long, R. L. Stanfield and F. C. Hentz Jr., J. Chem. Educ., 1979, 56, 195-196, DOI: 10.1021/ed056p195.

61 L. Bartošová, Z. Padělková, E. Rakovský and P. Schwendt, Polyhedron, 2012, 31, 565-569, DOI: 10.1016/j.poly.2011. 10.042.

62 (a) C. R. Groom, I. J. Bruno, M. P. Lightfoot and S. C. Ward, Acta Crystallogr., Sect. B: Struct. Sci., Cryst. Eng. Mater., 2016, 72, 171-179, DOI: 10.1107/S2052520616003954; (b) D. C. Crans, B. J. Peters, X. Wu and C. C. McLauchlan, Coord. Chem. Rev., 2017, 344, 115-130, DOI: 10.1016/j.ccr.2017.03.016; (c) S. R. Amanchi and S. K. Das, Front. Chem., 2018, 6, 469, DOI: 10.3389/fchem.2018.00469.

63 T. H. Li, J. Lü, S. Gao, F. Li, F. Li and R. Cao, Chem. Lett., 2007, 36, 356-357, DOI: 10.1246/cl.2007.356. 
64 G. C. Ou, L. Jiang, X. L. Feng and T. B. Lu, Dalton Trans., 2009, 71-76, DOI: 10.1039/B810802A.

65 L. Klištincová, E. Rakovský and P. Schwendt, Inorg. Chem. Commun., 2008, 11, 1141-1142, DOI: 10.1016/j.inoche.2008. 06.020 .

66 J. Thomas, M. Agarwal, A. Ramanan, N. Chernova and M. S. Whittingham, CrystEngComm, 2009, 11, 625-631, DOI: 10.1039/B815840A.

67 M. V. Pavliuk, V. G. Makhankova, O. V. Khavryuchenko, V. N. KokozayaIrin, I. V. Omelchenko, O. V. Shishkin and J. Jezierska, Polyhedron, 2014, 81, 597-606, DOI: 10.1016/ j.poly.2014.06.044.

68 L. Wang, X. Sun, M. L. Liu, Y. Q. Gao, W. Gu and X. Liu, J. Cluster Sci., 2008, 19, 531-542, DOI: 10.1007/s10876-008-0196-3.

69 M. Graia, R. Ksiksi and A. Driss, J. Chem. Crystallogr., 2008, 38, 855-859, DOI: 10.1007/s10870-008-9410-2.

70 H. Pang, X. Meng, H. Ma, B. Liu and S. Li, Z. Naturforsch., 2012, 67b, 855-859, DOI: 10.5560/ZNB.2012-0120.
71 W. Xu, F. Jiang, Y. Zhou, K. Xiong, L. Chen, M. Yang, R. Feng and M. Hong, Dalton Trans., 2012, 41, 7737-7745, DOI: 10.1039/c2dt30532a.

72 L. Klištincová, E. Rakovský and P. Schwendt, Acta Crystallogr., Sect. C: Cryst. Struct. Commun., 2009, 65, m97-m99, DOI: 10.1107/S0108270109001917.

73 J.-K. Li, C.-P. Wei, Y.-Y. Wang, M. Zhang, X.-R. Lv and C.-W. Hu, Inorg. Chem. Commun., 2018, 87, 5-7, DOI: 10.1016/j.inoche.2017.11.009.

74 Y. Qi, E. Wang, J. Li and Y. Li, J. Solid State Chem., 2009, 182, 2640-2645, DOI: 10.1016/j.jssc.2009.07.022.

75 S. Y. Samar and K. Das, J. Mol. Struct., 2017, 1146, 23-31, DOI: 10.1016/j.molstruc.2017.05.097.

76 P. Maurício, A. L. Franco, J. Rüdiger, J. F. Soares, G. G. Nunes and D. L. Hughes, Acta Crystallogr., Sect. E: Crystallogr. Commun., 2015, 71, 146-150, DOI: 10.1107/S2056989014028230.

77 C. Slebodnick and V. L. Pecoraro, Inorg. Chim. Acta, 1998, 283, 37-43, DOI: 10.1016/S0020-1693(98)00088-7. 